Kabul Tarihi:15.01.2019

\title{
Turizm ve Yiyecek Tüketimi: Uluslararası Alanyazın Üzerine Bibliyometrik Bir Analiz
}

\author{
Tourism and Food Consumption: A Bibliometric Analysis on International \\ Literature
}

\author{
Dr. Öğr. Üyesi Oğuz NEBioĞLU \\ Akdeniz Üniversitesi \\ Manavgat Turizm Fakültesi \\ E-posta: oguznebioglu@akdeniz.edu.tr
}

Öz

Araştırma son yıllarda turizmde popüler bir konu halini alan yiyecek tüketimi olgusunu betimsel analiz çerçevesinde doküman inceleme yöntemini kullanarak incelemeyi amaçlamaktadır. Web of Science veri tabanından "Tourism" ve "Food Consumption" kelimeleri birlikte aratılarak ulaşılan toplam 265 çalışma araştırmanın örneklemini oluşturmaktadır. Veriler Citespace II bibliyometrik analiz programı aracılığı ile yayın bilgileri, kelime analizleri, atıf bilgileri ve ülke iş birliktelikleri olmak üzere dört ana başlıkta analiz edilmiştir. Araştırma, yayınların yıllara göre dağılımını, bu konuda en fazla çalışmaya sahip yayınlar ve araştırma alanlarını, turizm ve yiyecek tüketimi konusunda öne çıkan anahtar kelimeleri, yıllara göre atıf dağılımlarını, atıf sayılarına göre çalışmaların sınıflandırıımasını, en fazla atıf alan ve en merkezi durumdaki çalışmalar ile yazarları ve söz konusu alana en fazla katkı sağlayan ülkeleri belirlemiştir. Araştırma sonuçlarının turizm ve yiyecek tüketimi konusuna ilgi duyanlara araştırma alanının genel eğilimleri bağlamında kapsamlı bir çerçeve çizdiği düşünülmektedir.

Anahtar Kelimeler: Turizm, Yiyecek Tüketimi, Bibliyometrik Analiz, Sosyal Ağ Analizi.

\begin{abstract}
The aim of the research is to examine the phenomenon of food consumption, which has become a popular topic in tourism in recent years, by using document analysis method within the framework of descriptive analysis. 265 studies reached by searching the "Tourism" and "Food Consumption" words on Web of Science database constitute the sample of the research. The data were analyzed in four main titles, as publication information, keyword analysis, citation information and country co-operation via the Citespace II bibliometric analysis program. Research has determined the distribution of publications by years, publications and research areas with the highest number of studies, key words about tourism and food consumption; categorization of studies according to the number of citations, the most cited and most centralized studies, authors and the most contributing countries. It is considered that the research results would enable individuals interested in tourism and food consumption to have an overview in the context of the general trends of the research area.
\end{abstract}

Key Words: Tourism, Food Consumption, Bibliometric Analysis, Social Network Analysis 


\section{Giriş}

İnsanların en temel gereksinimlerinden biri olan yiyecek tüketimi günümüzde turizmle ilişkilendirilen önemli bir çalışma alanı olarak görülmektedir (Beer vd. 2002; Corigliano, 2002; Ryu ve Jang, 2006). Yiyeceklerin, turistik destinasyonlar için önemli bir arz kaynağı olarak görülmeleri; turistlerin destinasyonda sunulan yiyeceklere karşı şekillenen eğilimleri gibi konular akademik açıdan ilgi duyulan bir alan olmaya başlamıştır. Bir arz kaynağı olarak yiyecekler, deniz, kum, güneş gibi turistik destinasyonların sahip olduğu doğal özelliklerin yanında bölgenin sosyokültürel yapısını yansıtan önemli bir unsur olarak (Harrington 2005; Çalışkan 2013; Nebioğlu 2017) kabul edilmektedir. Turistik talep açısından ise turistlerin bu kaynaklara yaklaşımı dikkat çekmektedir. Turistlerin ziyaret ettikleri destinasyonun yiyeceklerine karşı nasıl bir tutum ve davranış sergiledikleri, yemek deneyimi sonrasındaki memnuniyet, destinasyonu tekrar ziyaret etme niyeti ve başkalarına tavsiye etme durumu (Kim vd. 2009; Mak vd. 2012; Bayrakçı ve Akdağ, 2016) gibi konular son yıllarda alanyazında fazlaca yer kaplamaktadır.

Bibliyometri ilk olarak 1969 yılında Alan Pritchard tarafından kullanılan bir kavramdır (Ukşul 2016) ve belirli bir alandaki çalışmaların özelliklerini niceliksel analizlerle inceleyen bir araştırma yöntemi olarak tanımlanabilir (McBurney ve Novak 2002; Özel ve Kozak 2012). Günümüzde neredeyse tüm bilimsel alanlara uzanan disiplinler arası araştırma alanlarından biri konumuna gelmiştir (Glanzel 2003). Bibliyometri sayesinde ülke, yazar ve bir disipline ait ilişkilerin nicel verilere dökülerek analiz edilmesi kolaylaşır (Ukşul 2016). Bu şekilde alanyazındaki güncel konular, yöntemler, bulgular ve güncelliğini yitirmekte olan konular açığa çıkarılarak ilgili alanın genel gidişatı üzerinde bilgi verilebilir. Bu bağlamda bu araştırma uluslararası alanyazında turizm ve yiyecek tüketimi olgusunu bibliyometrik analiz yardımıyla incelemeyi planlamaktadır. Bu şekilde turizm ve yiyecek tüketimi ile ilgili çalışmaların hangi yönde gerçekleştiği ve hangi eğilimlere sahip olduğu konusunda daha bütüncül bir bakış açısı sunmayı hedeflemektedir.

\section{Kavramsal Çerçeve}

Bu bölümde, öncelikle turizm ve yiyecek tüketimi olgusunun kavramsal yapısı ortaya konmuş; devam eden kısımda da turizm ve yiyecek içecekler bağlamında bibliyometrik analiz yöntemini kullanan çalışmalara ilişkin bir inceleme gerçekleştirilmiştir.

\subsection{Turizm ve Yiyecek Tüketimi}

Turizm insanların çeşitli amaçlarla sürekli yaşadıkları çevrelerin dışındaki yerlere hareketlerini gerektiren sosyal, kültürel ve ekonomik bir olgu olarak tanımlanabilir (UNWTO, 2018). Turistik etkinliklerin başladığı ulaşım aşamasından itibaren konaklama tesislerine, turistlerin katıldığı etkinliklerden alışverişlere kadar yiyeceklerin, turizmin her aşamasında yer aldığı söylenebilir. Dünya Turizm Örgütü Gastronomi Turizmi Raporuna (2017) göre, bir bölgenin sahip olduğu yiyecekler, kültürel ve doğal unsurlardan sonra turistlerin seyahat motivasyonlarında etkili olan üçüncü en önemli neden olarak görülmektedir. Her şeyden önce yiyecek tüketimi fizyolojik bir zorunluluktur. Bunun yanında sosyo-kültürel, ekonomik ve psikolojik pek çok etkiye sahiptir (Richards 2002; Mak vd. 2012). Bu etki turizm arz ve talep boyutlarına ayrıldığında daha kolay anlaşılabilir. Turizm arzı açısından bakıldığında turistlerin tüketimine sunulan yiyecekler destinasyon imajının (Seo vd. 2014; Eren ve Kuvvetli, 2017) ve destinasyon pazarlama etkinliklerinin önemli bir parçası olarak kabul edilmektedir (DuRand vd. 2003; Kivela ve Crotts, 2006). Turizm talebi açısından 
bakıldığında ise turistlerin neyi tüketip neyi tüketmeyecekleri dikkat çekici bir konu olmaya başlamıştır. Özellikle bu aşamada yiyeceklere yüklenen anlam değer kazanmış ve turistlerin yiyeceğe olan bakış açıları merak edilen bir konu olmuştur. Bu durum da yiyecek tüketim davranışlarının gündelik yaşamın uzantısı ya da zıttı olması, rutin alışkanlıklara devam etme ya da rutinden kaçış gibi güdülerle açıklanmaya çalışılmıştır (Quan ve Wang, 2004). Turistlerin neyi tüketip tüketmedikleri konusunun yanında neden yiyecek tüketecekleri, başka bir ifadeyle yiyecek tüketimlerinin arkasında yatan motivasyon kaynakları da ilgi çekmektedir. Heyecan verici deneyim, rutinden kaçış, sağlık nedenleri, öğrenme, otantik deneyim, sosyalleşme, statü-prestij, duyuları tatmin etme ve fiziksel çevre (Fields, 2002, Kim vd. 2009; Silkes, 2012; Everett, 2012) alanyazında dikkat çeken motivasyon kaynakları olarak görülmektedir. Alanyazında turistlerin yiyecek tüketimlerini kolaylaştıran ya da zorlaştıran çeşitli eğilimler de çalışılmaktadır. Yeniliğe açık olma ya da yeniliğe kapalı olma durumları turizm ve yiyecek tüketimi kapsamında üzerinde durulan konulardır (Cohen ve Avieli, 2004; Mak vd. 2012). Yukarıdaki araştırmalardan da görüldüğü gibi turizm ve yiyecek tüketimi konusunun son yıllarda hızlı bir gelişim içinde olduğu ve oldukça çeşitli açılardan ele alınmaya başlandığı anlaşılmaktadır. Bu gelişim bibliyometrik çalışmalar özelinde de görülebilir. Bu bağlamda aşağıda turizm ve yiyecek içecekler bağlamında yapılan bibliyometrik çalışmalar ele alınmıştır.

\subsection{Turizm ve Yiyecek İçecekler Bağlamında Bibliyometrik Çalışmalar}

Ulusal ve uluslararası alanyazın incelendiğinde turizm alanyazınındaki bibliyometrik çalışmaların sayısının 2000'li yılların başında artmaya başladığı söylenebilir (Köseoğlu vd. 2016). Bu çalışmalar öncelikle turizm araştırmalarının genel eğilimleri üzerinde durmuş; bazıları akademik makale bulgularını analiz ederek (Hall, 2011; Çiçek ve Kozak 2012; Zencir ve Kozak 2012; Karagöz ve Kozak 2014); bazı çalışmalar hem bildiri hem de makaleleri inceleyerek (Köseoğlu vd. 2016) bazıları ise turizm alanındaki lisansüstü tezleri ele alarak (Güçlü-Nergiz 2014; Tayfun vd. 2016) turizmin akademik eğilim ve yönelimleri hakkında fikir vermeyi amaçlamıştır. Örneğin Palmer vd. (2005) turizm konulu akademik çalışmalarda kullanılan istatistiksel yöntemler üzerinde bir çalışma gerçekleştirmiş; 1998-2002 yıllarında 12 turizm dergisinde yer alan toplam 1790 çalışmayı kullanılan istatistiksel teknikler bakımından analiz ederek turizm alanındaki çalışmalara metodolojik açıdan bir bakış geliştirmeyi hedeflemiştir. Çiçek ve Kozak (2012) tarafından yapılan çalışma Anatolia Turizm Araştırmaları dergisinde yayınlanan hakem denetimli makalelerin bibliyometrik profilini ortaya koymayı amaçlamıştır. 3 farklı dönem baz alınarak yapılan bibliyometrik analizlerde ilk dönemde turizmle ilgili genel konulara; ikinci dönemde turizm pazarlamasına; üçüncü dönemde ise turizmde yönetim konusuna ağırlık verildiği anlaşılmıştır. Zencir ve Kozak (2012) tarafından yapılan araştırmada ülkemizde sosyal bilimler enstitüsü dergilerinde turizm konusunda yayınlanan 206 makale incelenmiştir. Araştırma bulguları turizm pazarlaması ve turizmde yönetim konularının ağılıkta olduğunu göstermektedir. Karagöz ve Kozak (2014) tarafından yapılan araştırmada Anatolia Turizm Araştırmaları dergisinde yer alan makaleler araştırma konuları ve kurumlararası işbirliği çerçevesinde incelenmiştir. Turizm alanyazınının disiplinlerarası bir alan olmasından çok merkezi bir alan olma eğiliminde olduğu; Dokuz Eylül, Gazi ve Mersin Üniversitelerinin bilimsel bilgi üretiminde merkezde yer aldıkları anlaşılmıştır. GüçlüNergiz'in (2014) çalışmasında 1990-2013 yılları arasında ülkemizde yayınlanan lisansüstü tezler analiz edilmiştir. Toplamda 2348 çalışmanın ele alındığı araştırma bulguları yüksek lisans tezlerinin turizm, işletme ve mimarlık konularına; doktora tezlerinin ise turizm, işletme ve coğrafya konularına odaklandıklarını göstermektedir. Tayfun vd. (2016) tarafından yapılan araştırma da benzer biçimde yüksek lisans tezlerine odaklanmıştır. 1985-2016 yılları arasında Gazi Üniversitesi bünyesinde 
hazırlanan turizm konulu 367 tezin iki dönemde incelendiği araştırmanın bulguları ilk dönemde turizm ile pazarlama araştırmalarına ikinci dönemde ise yönetim ve organizasyon araştırmalarına ağırlık verildiğini göstermektedir. Yukarıda bahsi geçen tüm çalışmaların bir bütün halinde turizm alanyazınının gelişimini açıklamayı hedeflediklerini söylemek mümkündür.

Turizm ile farklı disiplinlerin ya da turizmle birlikte ele alınan spesifik konuların birlikte incelendiği bibliyometrik araştırmalara da rastlanmaktadır. Turizm alanyazınının genelinin bibliyometrik analizinin yapılmasına ek olarak zamanla turizmin farklı disiplinlinlerle olan ilişkisi de incelenmeye başlanmıştır. Turizm pazarlaması (Özel ve Kozak 2012); turizmle ilişkili psikoloji araştırmaları (Barrios vd. 2008); turizm talebine odaklanan çalışmalar (Aydın-Arslan vd. 2016) bunlara örnek olarak gösterilebilir. Örneğin Özel ve Kozak (2012) tarafından yapılan araştırma turizm pazarlaması alanının 2000-2010 yılları arasındaki gelişim sürecini incelemiştir. Araştırma bulguları yabancı kaynakların yerli kaynaklardan daha fazla atıf aldığını vurgulamıştır. Barrios vd. (2008) tarafından yapılan araştırmanın bulguları turizm psikolojisi alanyazınının son yıllarda önemli bir gelişim gösterdiğini vurgulamıştır. Bu konuda önemli ölçüde işbirliğinin ve kurumsal ortaklığın geliştiği ifade edilmiştir. Aydın-Arslan vd. (2016) tarafından yapılan araştırma ise turizm talebi üzerine yapılan çalışmaların 2000'li yıllardan itibaren artış göstermeye başladığı, Çin ve İngiltere'nin turizm talebi üzerinde en fazla yayın yapan ülkeler oldukları ve Tourism Management ile Annals of Tourism Research dergilerinin bu konuda en fazla yayın yapan dergiler oldukları sonucuna ulaşmıştır.

Pazarlama, psikoloji gibi disiplinlerin turizmle birlikte ele alındığı çalışmaları analiz eden bibliyometrik çalışmaların yanında turizm olgusunun farklı yönlerini inceleyen bibliyometrik çalışmalar da görülmektedir. Turizm rehberliği (Şahin ve Acun 2015), kırsal turizm (Bozok vd. 2017); sağlık turizmi (Temizkan vd. 2015); sürdürülebilir turizm (Erkol-Bayram vd. 2017); turizm alanında engellilerle ilgili yapılan çalışmalar (Cevizkaya vd. 2014) turizm olgusunun farklı kesitlerini irdeleyen bibliyometrik çalışmalardır. Sözgelimi Şahin ve Acun (2015) tarafından yapılan çalışma turist rehberliği alanının gelişimini incelemek üzere Ulusal Turizm Kongrelerinde yer alan bildirileri bibliyometrik analize tabi tutmuştur. Turizm rehberliği konusunda en fazla çalışılan konunun eğitim olduğu görülmüştür. Bozok vd. (2017) tarafından yapılan araştırma kırsal turizm konusundaki araştırmaların son yirmi yılda artış gösterdiğini ifade etmektedir. Temizkan vd. (2015) tarafından sağlık turizmi konusunda yapılan araştırmada hem ulusal hem de uluslararası alanyazın taranmış; bulgular yerli çalışmaların sağlık turizminde termal turizm konusuna; yabancı kaynakların ise tıbbi tedavi konusuna yoğunlaştıklarını göstermiştir. Erkol-Bayram (2017) tarafından yapılan araştırma ise ülkemizde sürdürülebilir turizm alanyazınının gelişimi hakkında bilgiler sunmuştur.

Son zamanlarda bibliyometrik araştırmalar bağlamında turizm olgusunun birlikte ele alındığı alanlardan biri de yiyecek içecek ya da gastronomi konusudur. Sayıca oldukça az olan bu çalışmalar ulusal turizm kongrelerinde gastronomi ve mutfak sanatları alanında sunulan bildirileri (Yılmaz 2017); turizm alanında yazılmış gastronomiye ilişkin tezleri (Sünnetçioğlu vd. 2017) inceleyerek turizm ve gastronomi konusundaki genel eğilimleri belirlemeyi hedeflemiştir. Bu alanda yapılan bir başka çalışma ise söz konusu çalışmalardan farklı olarak turizm ve gastronomi alanının daha spesifik bir boyutunu ele almış ve şarap turizmi konusunda yayımlanan makaleleri (Sanchez vd. 2017) incelemiştir. Yılmaz (2017) tarafından yapılan çalışma ulusal turizm kongrelerinde gastronomi ve mutfak sanatları alanında yayımlanan bildirilere odaklanmıştır. 2009-2015 yılları arasında gerçekleştirilen turizm kongrelerinde ulaşılan 
63 bildiri sayfa sayısı, kaynak sayısı, araştırma yöntemi gibi 17 farklı parametrede analiz edilmiştir. Söz konusu araştırma bu alanda alanyazına en fazla katkı yapan kurumun Mersin Üniversitesi olduğunu; en fazla katkı yapan akademisyenlerin de Dr. Öğr. Üyeleri olduğunu ifade etmiştir. Sünnetçioğlu vd. (2017) tarafından yapılan araştırma turizm alanında yazılmış gastronomiye ilişkin tezleri incelemiştir. Söz konusu çalışma YÖK Ulusal Tez Merkezinde yayımlanan 33 yüksek lisans tezini 13 farklı parametre çerçevesinde incelemiştir. Araştırma bulguları tez çalışmalarının örneklem grubunun genellikle yabancı turistlerden oluştuğunu, en fazla kullanılan veri toplama yönteminin anket yöntemi olduğunu göstermektedir. Turizm ve gastronomi konularını ele alan tez sayısının son yıllarda önemli bir artış gösterdiği anlaşılmaktadır. Sanchez vd. (2017) tarafından yapılan çalışmada ise şarap turizmi alanında Web of Science ve Elsevier Scopus veri tabanlarında taranan 238 makale bibliyometrik analize tabi tutulmuştur. Yayınlar yazar, dergi, ülke ve anahtar kelime gibi 8 farklı parametrede incelenmiştir. Araştırma bulguları son 5 yılda yapılan şarap turizmi çalışmalarının tüm çalışmaların \%60‘nı oluşturduğunu göstermektedir. Özellikle Amerika ve Avustralya kıtalarında şarap turizmi çalışmalarının daha yoğun olduğu anlaşılmaktadır.

Yukarıda ayrıntılı olarak verilen çalışma bulgularından da anlaşılacağı üzere, turizm alanyazını bibliyometrik çalışmalar bağlamında genelden özele doğru seyreden bir yapı sergilemektedir. Bir başka ifadeyle önceleri genel olarak turizm araştırmalarının eğilimlerinin ele alındığı çalışmalar zamanla turizmin farklı disiplinlerle olan ilişkilerini incelemeye odaklanmıştır. Bibliyometrik bağlamda gelişen ve çeşitlenen turizm araştırmaları sağlık turizmi; sürdürülebilir turizm, kırsal turizm gibi daha spesifik alanlara odaklanmaya başlamıştır. Bu noktadan yola çıkarak bu araştırma benzer biçimde turizm ve yiyecek tüketimi konusunu uluslararası alanyazından yararlanarak bibliyometrik analiz yöntemiyle ele almayı amaçlamaktadır. Bu amaç doğrultusunda turizm ve yiyecek tüketimi konusuna odaklanarak bu alandaki yayın, yazar, atıf bilgilerini ortaya koymayı; anahtar kelime analizi gerçekleştirmeyi ve ülke iş birlikteliklerini açığa çıkarmayı planlamaktadır. Bu yolla turizm ve gastronomi çerçevesinde yiyecek tüketimi konusundaki çalışmaların genel eğilimleri ve gelecekteki çalışma trendleri konusunda bilgi sahibi olunması hedeflenmektedir.

\section{Yöntem}

Bu çalışma, betimsel analiz çerçevesinde doküman inceleme yöntemi kullanılarak yapılmıştır. Verilerin toplanmasında Web of Science Core Collection veri tabanı tercih edilmiştir. Web of Science Core Collection 250'den fazla bilimsel disiplinde, 20000'den fazla hakemli, bilimsel dergiden oluşan önemli bir veri tabanıdır (https://clarivate.libguides.com/woscc). Bibliyometrik araştırmalarda en önemli veri kaynakları SCl, SSCl, A\&HCl bilimsel atıf indeksleridir ve bu indekslere Web of Science Core Collection veri tabanı yardımıyla erişim sağlanmaktadır (Güzeller ve Çeliker 2018:89). Bununla birlikte birçok akademik araştırmada kullanılan Web of Science Core Collection, Elsevier Scopus'la birlikte bibliyometrik çalışmalar için temel olarak kullanılan bir veri tabanı olduğundan (Aydınoğlu ve Taşkın 2017) bu araştırmada da bibliyometrik analiz için ulaşılan verilerin elde edilmesinde tercih edilmiştir. Araştırma verileri 1970 ve 2018 yılları arasında Web of Science veri tabanında taranan dergilerde yayımlanan çalışmaların bilgilerinden elde edilmiştir. Söz konusu veri tabanının arama sayfasında "Tourism" ve "Food Consumption" kelimeleri birlikte aratılmış, toplamda 265 kaynağa erişilmiş ve erişilen tüm kaynaklar değerlendirmeye uygun görülmüştür. Ulaşılan kaynakların analizi dört farklı kategoride gerçekleştirilmiş olup Tablo 1 çalışmada kullanılan analizleri ayrıntılı olarak göstermektedir. Bu kapsamda ilk olarak veriler yayın bilgileri yönünden incelenmiştir. 
Yayınların yıllara göre dağılımları, yayın türleri, yayınlandıkları yerler ve alanlar analiz edilmiştir.

Tablo 1: Çalışmada Kullanılan Analizler

\begin{tabular}{|c|c|}
\hline Analizler & Açıklamalar \\
\hline Yayın Bilgileri & $\begin{aligned} & \text { Bu kısımda yayınların; } \\
& \text { - } \text { Yıllara, } \\
& \text { - } \text { Alanlarına, } \\
& \text { - } \text { Yayınlandıkları yerlere ve } \\
& \text { - } \text { Türlerine göre dağılımı üzerinde durulmuştur. }\end{aligned}$ \\
\hline $\begin{array}{l}\text { Anahtar Kelime } \\
\text { Analizleri }\end{array}$ & $\begin{array}{l}\text { Bu kısımda yayınların; } \\
\text { - } \quad \text { Anahtar Kelime Ağı ortaya çıkarılmıs olup en çok kullanılan } \\
\text { anahtar kelimeler ile bu kelimelerin merkezilik dereceleri } \\
\text { ele alınmıştır. }\end{array}$ \\
\hline Atıf Bilgileri & $\begin{array}{cl}\text { Bu kısımda; } \\
\text { - } \quad \text { Yıllara göre atıf dağı̆ımı } \\
\text { - } \quad \text { Yayın sayısına göre atıf sayıları } \\
\text { - } \quad \text { Ortak atıf alan yazarlar ve merkezilik dereceleri } \\
\text { - } \quad \text { Atıf kaynaklarının aldıkları atıf sayıları ve merkezilik } \\
\text { - } \quad \text { dereceleri } \\
\text { - Dergi ortak atıf ağı ve merkezilik dereceleri incelenmiştir. }\end{array}$ \\
\hline Ülke İş Birliktelikleri & $\begin{array}{l}\text { Bu kısımda; } \\
\begin{array}{l}\text { - Ülke iş birliktelikleri ve merkezilik dereceleri analiz } \\
\text { edilmiştir. }\end{array}\end{array}$ \\
\hline
\end{tabular}

Turizm ve yiyecek tüketimi konusuna odaklanan çalışmalarda en fazla kullanılan anahtar kelimelerin belirlenmesi, söz konusu alana en fazla katkı sağlayan yazarların ortaya çıkarılması ve ülke iş birliktelikleri gibi konuların incelenmesinde sosyal ağ analizinden yararlanılmıştır. Sosyal ağ analizi için de Citespace II programı kullanılmıştır. Citespace II programı ortak atıf ağlarını analiz etmeyi ve görselleştirmeyi sağlayan bir java uygulamasıdır (Chen 2006:393). Web of Science Core Collection'dan elde edilen 265 yayına ilişkin veriler Citespace II programı için uygun formata dönüştürülerek yüklenmiş ve analizler gerçekleştirilmiştir. Söz konusu program yardımıyla ağ yoğunluğu, ağın mean silhouette ve modularity değerleri hesaplanmıştır. Ağ yoğunluğu bir ağda, potansiyel olarak kullanılabilecek bağlantıların ne kadarının kullanıldığını göstermektedir (Al ve Doğan, 2012: 354; Aktaran Güzeller ve Çeliker 2017). Mean silhouette değeri -1 ile +1 arasında olur. 1'e yakın değerler ağdaki elemanların içerik açısından oldukça tutarlı ve benzer olduklarını gösterir. Modularity değeri (Q) 0-1 arasında olur, 1'e yakın değerler kümeler arasındaki yakın ilişkileri gösterir. Söz konusu değerin 0,4 ile 0,8 arasında olması iyi bir kümelenmeyi ifade eder (Li vd. 2017). Merkezilik derecesi ağdaki düğümlerin konumunun önemini ölçmektedir ve ağdaki potansiyel kilit noktaları vurgulamaktadır (Güzeller ve Çeliker 2018).

\section{Bulgular}

Aşağıda bibliyometrik analiz bulgularına yer verilmektedir. Bu bağlamda öncelikle turizm ve yiyecek tüketimi konusunda yapılan yayınlarla ilgili bilgiler yer almaktadır. Tablo 2 yayınların yıllara göre dağılımını göstermektedir. Söz konusu veri tabanında 1970-1990 yılları arasında turizm ve yiyecek tüketimi konusunda hiçbir çalışmaya rastlanamamıştır. Turizm ve yiyecek tüketimi ile ilgili yayınların 1991-2000 yıllarına ait dönemde başladığı ve 2010 yılına kadar yavaş bir gelişim sergilediği görülmektedir. 2011 yılından günümüze kadar gelen dönemde ise turizm ve yiyecek tüketimi olgusunun oldukça yoğun bir biçimde ele alındığı görülmektedir. Söz konusu dönem toplam yayınların \%78,1 gibi büyük bir bölümünü kapsadığından böyle bir yoğunluktan söz etmek doğru olacaktır. 
Tablo 2: Yayınların Yıllara Göre Dağılımı

\begin{tabular}{|l|l|l|}
\hline Yıllar & Frekans (n) & Yüzde (\%) \\
\hline $1970-1980$ & - & - \\
\hline $1981-1990$ & - & - \\
\hline $1991-2000$ & 5 & 1,9 \\
\hline $2001-2010$ & 53 & 20,0 \\
\hline $2011-$ günümüz & 207 & 78,1 \\
\hline TOPLAM & $\mathbf{2 6 5}$ & $\mathbf{1 0 0}$ \\
\hline
\end{tabular}

Tablo 3 yayınların türlerine ve yayımlandığı yerlere göre dağılımını göstermektedir. Turizm ve yiyecek tüketimi konusunun çoğunlukla makalelerde ele alındığı $(\% 81,1)$ görülmektedir. Bunu bildiriler $(\% 13,9)$ ve mektuplar $(\% 4,2)$ izlemektedir.

Tablo 3: Yayınların Türlerine ve Yayınlandığı Yerlere Göre Dağılımı

\begin{tabular}{|c|c|c|c|}
\hline $\begin{array}{l}\text { Yayın } \\
\text { Türü }\end{array}$ & Yayınlandığı Yer & $\begin{array}{c}\text { Frekans } \\
\text { (n) }\end{array}$ & $\begin{array}{c}\text { Yüzde } \\
(\%)\end{array}$ \\
\hline \multirow{31}{*}{ Makale } & Tourism Management & 15 & 5,7 \\
\hline & Journal of Sustainable Tourism & 14 & 5,3 \\
\hline & British Food Journal & 11 & 4,2 \\
\hline & International Journal of Hospitality Management & 10 & 3,8 \\
\hline & Tourism Economics & 6 & 2,3 \\
\hline & Tourism Geographies & 5 & 1,9 \\
\hline & Annals of Tourism Research & 5 & 1,9 \\
\hline & Journal of Travel Research & 5 & 1,9 \\
\hline & Scandinavian Journal of Hospitality and Tourism & 5 & 1,9 \\
\hline & International Journal of Tourism Research & 4 & 1,5 \\
\hline & Tourism Management Perspectives & 4 & 1,5 \\
\hline & Asia Pacific Journal of Tourism Research & 3 & 1,2 \\
\hline & Current Issues in Tourism & 3 & 1,2 \\
\hline & Hospitality \& Society & 3 & 1,2 \\
\hline & International Journal of Contemporary Hospitality Management & 3 & 1,2 \\
\hline & Journal of Cleaner Production & 3 & 1,2 \\
\hline & Journal of Industrial Ecology & 3 & 1,2 \\
\hline & Sustainability & 3 & 1,2 \\
\hline & Almatourism - Journal Of Tourism Culture And Territorial Development & 2 & 0,7 \\
\hline & Anatolia - International Journal of Hospitality and Tourism Research & 2 & 0,7 \\
\hline & Appetite & 2 & 0,7 \\
\hline & Ecumene (Journal of Cultural Geographies) & 2 & 0,7 \\
\hline & European Journal of Tourism Research & 2 & 0,7 \\
\hline & European Planning Studies & 2 & 0,7 \\
\hline & Environmental Science and Pollution Research & 2 & 0,7 \\
\hline & Interciencia & 2 & 0,7 \\
\hline & Nature + Culture & 2 & 0,7 \\
\hline & Journal of Environmental Protection & 2 & 0,7 \\
\hline & Journal of Environmental Protection and Ecology & 2 & 0,7 \\
\hline & Journal of Hospitality and Tourism Research & 2 & 0,7 \\
\hline & Journal of Rural Studies & 2 & 0,7 \\
\hline & Journal of Travel and Tourism Marketing & 2 & 0,7 \\
\hline & Journal of the Science of Food and Agriculture & 2 & 0,7 \\
\hline & Tourist Studies & 2 & 0,7 \\
\hline & Diğer & 78 & 29,5 \\
\hline
\end{tabular}


Tablo 3'ün devamı

\begin{tabular}{|l|l|c|c|}
\hline \multirow{4}{*}{ Bildiri } & Procedia-Social and Behavioral Sciences & 4 & 1,5 \\
\cline { 2 - 4 } & $\begin{array}{l}\text { Hospitality And Tourism: Synergizing Creativity And Innovation } \\
\text { Research }\end{array}$ & 3 & 1,2 \\
\cline { 2 - 4 } & 1 st International Hospitality and Tourism Postgraduate Conferenc & 3 & 1,2 \\
\cline { 2 - 4 } & Diğer & 27 & 10,2 \\
\hline \multirow{2}{*}{ Mektup } & Turizmle ilgili dergiler & 2 & 0,7 \\
\cline { 2 - 4 } & Diğer & 9 & 3,4 \\
\hline $\begin{array}{l}\text { Kitap } \\
\text { Özeti }\end{array}$ & Physical Planning in Tourism & 1 & 0,4 \\
\hline Editoryal & Scandinavian Journal of Hospitality and Tourism & 1 & 0,4 \\
\hline TOPLAM & $\mathbf{2 6 5}$ & $\mathbf{1 0 0}$ \\
\hline
\end{tabular}

Analize tabi tutulan yayınlar arasında 1 kitap özeti ile 1 adet editoryal bulunmaktadır. Turizm ve yiyecek tüketimi konusunun en fazla ele alındığı derginin Tourism Management (15 makale) olduğu görülmektedir. Onu Journal of Sustainable Tourism (14 makale) ve British Food Journal (11 makale) izlemektedir. Bu üç derginin turizm ve yiyecek tüketimi konusunda önde gelen kaynaklar olduğu ifade edilebilir.

Tablo 4: Çalışmaların Yayın Alanlarına Göre Dağılımı

\begin{tabular}{|l|l|l|}
\hline Yayın Alanları & Yayın Sayıları & Yüzde (\%) \\
\hline Hospitality, Leisure, Sports and Tourism & 79 & 29,8 \\
\hline Environmental Sciences & 39 & 14,7 \\
\hline Green Sustainable Science Technology & 29 & 10,9 \\
\hline Food Science and Technology & 17 & 6,4 \\
\hline Business & 11 & 4,2 \\
\hline Economy & 10 & 3,7 \\
\hline Ecology & 8 & 3,1 \\
\hline Management & 6 & 2,2 \\
\hline Diğer & 66 & 25,0 \\
\hline TOPLAM & $\mathbf{2 6 5}$ & $\mathbf{1 0 0}$ \\
\hline
\end{tabular}

Tablo 4 yayınların yayın alanlarına göre dağııımını göstermektedir. Bu bağlamda doğal olarak Hospitality, Leisure, Sports and Tourism alanı yayınların büyük kısmını $(\% 29,8)$ kapsamaktadır. Bu alanı Environmental Sciences $(\% 14,7)$; Green Sustainable Science Technology $(\% 10,9)$ alanı izlemektedir.

Tablo 5: Anahtar Kelimeler ve Merkezilikleri

\begin{tabular}{|l|l|l|l|l|l|}
\hline Kelimeler & Frekans & Yıl & Kelimeler & Merkezilik & YıI \\
\hline Tüketim & 68 & 2011 & Seyahat & 0,23 & 2012 \\
\hline Turizm & 58 & 2011 & Yerel Yiyecek & 0,22 & 2009 \\
\hline Yiyecek & 37 & 2010 & Kalite & 0,19 & 2016 \\
\hline Deneyim & 33 & 2011 & Deneyim & 0,16 & 2011 \\
\hline Yerel Yiyecek & 29 & 2009 & Otantizm & 0,15 & 2010 \\
\hline Model & 19 & 2013 & Memnuniyet & 0,14 & 2013 \\
\hline Yönetim & 18 & 2013 & Tüketim & 0,13 & 2011 \\
\hline Otantizm & 13 & 2010 & Yiyecek & 0,12 & 2010 \\
\hline Kimlik & 13 & 2014 & Planlı DavranıS & 0,12 & 2015 \\
\hline Memnuniyet & 12 & 2013 & Sürdürülebilir Turizm & 0,12 & 2015 \\
\hline
\end{tabular}

Bulguların bu kısmında anahtar kelime analizleri yer almaktadır. Tablo 5 turizm ve yiyecek tüketimi konusunda en fazla kullanılan 10 anahtar kelimeyi göstermektedir. Illk üç sırada yer alan tüketim, turizm ve yiyecek kelimeleri dışında deneyim, yerel yiyecek ve model gibi kelimelerin ön plana çıktıkları görülmektedir. Bu şekilde turizm ve 
yiyecek tüketimi konusundaki araştırmalarda kullanılan deneyim, yerel yiyecek ve model kelimelerinin ön plana çıkan anahtar kelimeler oldukları ifade edilebilir. Bunlara ek olarak Tablo 5'te en merkezi 10 anahtar kelime de yer almaktadır. Bu bağlamda "seyahat" kelimesinin en merkezi anahtar kelime olduğu onu yerel yiyecek ve kalite kelimelerinin izlediği görülmektedir. Buradan hareketle söz konusu kelimelerin turizm ve yiyecek tüketimi konusundaki bilimsel araştırmalarda kilit rol üstlendikleri söylenebilir.

\section{Şekil 1: Uluslararası Yayınların Anahtar Kelime Ağı}

Cite Space, v. 5.2.R2 (32-bit)

WoS: E:IYAPIMI SURREN ÇALIŞMALARITurizmde Yiyecek Tüketi mi - Uluslararası Alanyazın Üzerine Bibliyometrik Bir AnalizlTurizmde Yiyecek Tüketi milData Timespan: 1990-2018 (Slice Length=1)

Timespan: $1990-2018$ (Slice Length $=1$ )
Selection Criteria: Top 50 per slice $T C=[5,10], L R F=2, L B Y=8, e=2.0$
Network: $N=122, E=289$ (Density $=0.0392$ )

Largest CC: $114(93 \%)$

Nodes Labeled: $5.0 \%$
Pruning: Pathfinder

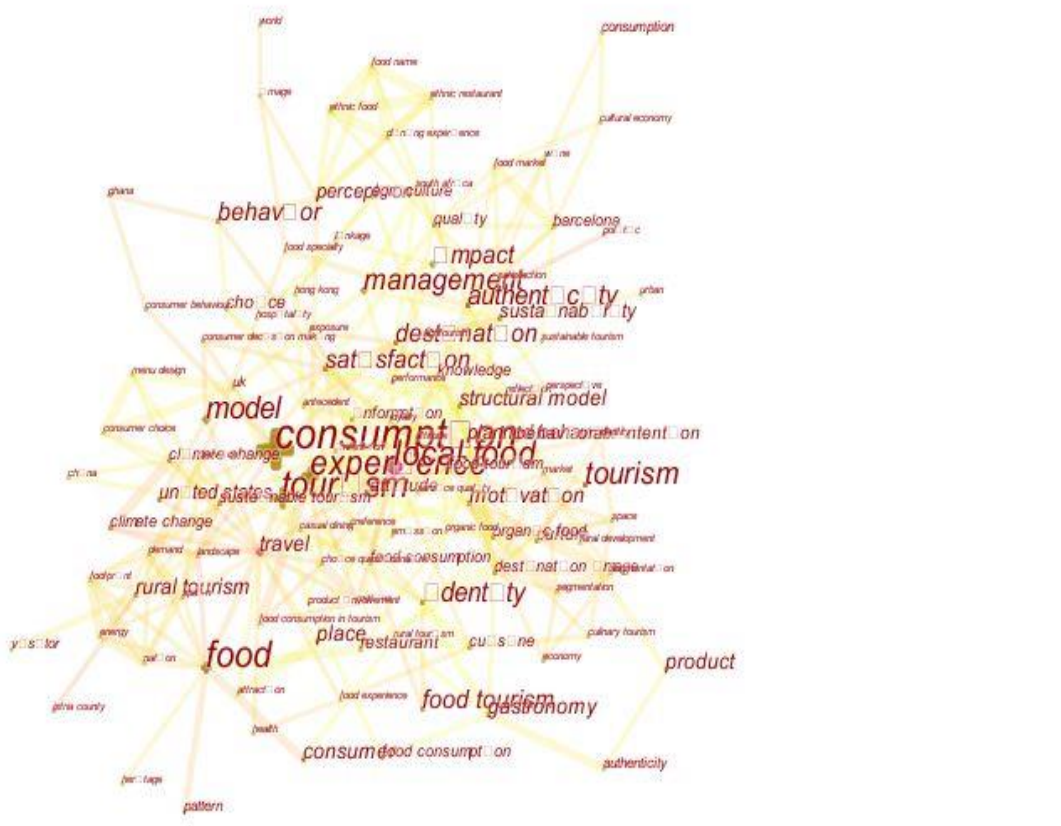

Turizm ve yiyecek tüketimi konusunda yapılan araştırmalarda sıklıkla kullanılan anahtar kelimeler ve bu kelimelerin birbirleri arasındaki ilişkiler Şekil 1'de görülmektedir. Ağ 122 düğüm (anahtar kelime sayısı), bu kelimelerin oluşturduğu 289 bağlantı ve 15 kümeden oluşmaktadır. Ağın yoğunluğu 0,0392; mean silhouette değeri 0,3408 ve modularity değeri de 0,5973'tür. Bu değerlerden ağın homojene yakın bir yapıya sahip olduğu ve yeterli sayılabilecek küme sayısına ayrıldığı söylenebilir.

Tablo 6: Yıllara Göre Atıf Dağılımı

\begin{tabular}{|l|l|l|}
\hline Yıllar & Alınan Atıf Sayıları (n) & Yüzde (\%) \\
\hline $1991-2000$ & 337 & 8,4 \\
\hline $2001-2010$ & 2106 & 52,5 \\
\hline $2011-$ günümüz & 1571 & 39,1 \\
\hline TOPLAM & $\mathbf{4 0 1 4}$ & $\mathbf{1 0 0}$ \\
\hline
\end{tabular}

Bulguların üçüncü bölümünde atıf bilgileri yer almaktadır. Atıf analizi çalışmalarının bibliyometride önemli bir yeri bulunmaktadır (Özel ve Kozak, 2012). Tablo 6 yıllara göre atıf dağılımını göstermekte ve atıflar üç farklı dönemde ele 
alınmaktadır. Yıllara göre atıf sayıları incelendiğinde en fazla atıf alınan yılların 20012010 yılları arasındaki dönem olduğu görülmektedir. Bu dönem aynı zamanda tüm atıfların \%52,5'ini oluşturmaktadır. En fazla atıf yapılan çalışmaların 2012 yılında yayınlanan çalışmalara geldiği $(n=553)$ görülmektedir.

Tablo 7: Yayın Sayısına Göre Atıf Sayıları

\begin{tabular}{|l|l|l|}
\hline Atıf SayıSı & Yayın Sayıları (n) & Yüzde (\%) \\
\hline 201 ve üzeri & 3 & 1,1 \\
\hline $101-200$ & 5 & 1,9 \\
\hline $51-100$ & 12 & 4,5 \\
\hline $11-50$ & 61 & 23,0 \\
\hline $1-10$ & 93 & 35,2 \\
\hline 0 & 91 & 34,3 \\
\hline TOPLAM & $\mathbf{2 6 5}$ & $\mathbf{1 0 0}$ \\
\hline
\end{tabular}

Tablo 7 yayın sayısına göre atıf sayıları hakkında bilgiler sunmaktadır. 201 ve üzeri atıf alan çalışmaların sayısının tüm çalışmaların \%1,1'ini oluşturduğu görülmektedir. 91 çalışmanın ise henüz hiç atıf almadığı anlaşılmaktadır.

Tablo 8: Ortak Atıf Alan Yazarların Atıf Sayıları ve Merkezilik Dereceleri

\begin{tabular}{|l|l|l|l|l|l|}
\hline Yazarlar & Atıf Sayısı & Yıl & Yazarlar & Merkezilik & Yıl \\
\hline Cohen E. & 58 & 2012 & Anonymous & 0,19 & 2012 \\
\hline Hall C. M. & 42 & 2012 & McKercher B. & 0,19 & 2014 \\
\hline Kim Y. G. & 39 & 2012 & Okumuş B. & 0,18 & 2013 \\
\hline Mak A. & 37 & 2012 & Becken S. & 0,17 & 2016 \\
\hline Quan S. & 36 & 2012 & Frochot I. & 0,17 & 2013 \\
\hline Anonymous & 33 & 2012 & Torres R. & 0,15 & 2012 \\
\hline Sims R. & 32 & 2015 & Ryan C. & 0,15 & 2013 \\
\hline Hjalager A. M. & 29 & 2012 & Bessiere J. & 0,14 & 2012 \\
\hline Chang R. & 28 & 2012 & Quan S. & 0,13 & 2012 \\
\hline Bessiere J. & 25 & 2012 & Wang N. & 0,13 & 2013 \\
\hline
\end{tabular}

Tablo 8 alanda bulunan 265 çalışmada en fazla atıf alan 10 yazarı ve merkezilik dereceleri en yüksek olan 10 yazarı göstermektedir. En fazla ortak atıf alan yazarın Cohen E. $(n=58)$ olduğu anlaşılmaktadır. Merkezilik derecesi en yüksek olan yazarların ise Anonymous adı altındaki ismi belirlenemeyen yazarlar olduğu anlaşılmaktadır. Onu aynı merkezilik derecesi ile $(C=0,19)$ McKercher $\mathrm{B}$. İzlemektedir. Bu bağlamda merkezilik derecesi yüksek olan yazarların atıf alma konusunda kilit rol üstlendikleri ifade edilebilir.

Şekil 2 yazar ortak atıf ağını göstermektedir. Yazar ortak atıf ağı, 270 düğüm (atıf kaynağı yazarlar), 538 bağlantı ve 66 kümeden oluşmaktadır. Yoğunluğu 0.0148 'dir. Bu durum ağın düşük yoğunluğa sahip olduğunu göstergesidir. Mean silhouette değeri ise 0.3012 'dir. Söz konusu ağın Modularity değeri $Q=0.7765$ olarak hesaplanmıştır. Bu noktada ağın homojene yakın olduğu ve yeterince kümeye ayrıldığı söylenebilir. 
Şekil 2: Yazar Ortak Atıf Ağı

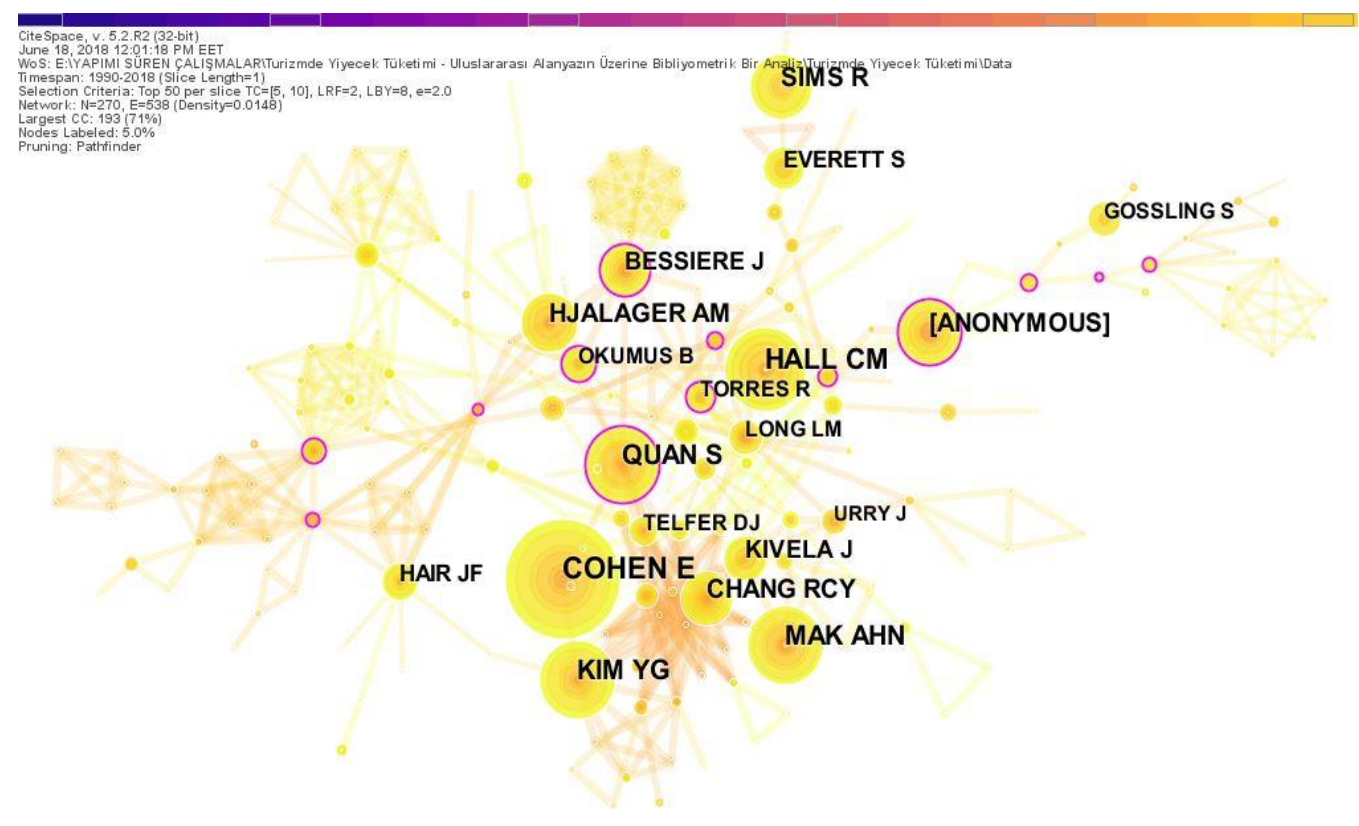

Tablo 9: Atıf Kaynaklarının Aldıkları Atıf Sayıları

\begin{tabular}{|l|l|l|}
\hline Yayınlar & Atıf Sayısı & Yıl \\
\hline $\begin{array}{l}\text { Kim Y. G., Eves A. ve Scarles C. (2009). Building a model of local food } \\
\text { consumption on trips and holidays: A grounded theory approach. }\end{array}$ & 23 & 2009 \\
\hline $\begin{array}{l}\text { Mak A. H. N., Lumbers M. ve Eves A. (2012). Globalisation and food } \\
\text { consumption in tourism. }\end{array}$ & 22 & 2012 \\
\hline $\begin{array}{l}\text { Sims R. (2009). Food, place and authenticity: local food and the } \\
\text { sustainable tourism experience. }\end{array}$ & 22 & 2009 \\
\hline $\begin{array}{l}\text { Chang R. C. Y. Kivela J. Mak A. H. N. (2010). Food preferences of } \\
\text { chinese tourists. }\end{array}$ & 21 & 2010 \\
\hline $\begin{array}{l}\text { Mak A. H. N. Lumbers. Eves A. Chang R. C. Y. (2012) Factors } \\
\text { influencing tourist food consumption. }\end{array}$ & 19 & 2012 \\
\hline $\begin{array}{l}\text { Chang R. C. Y. Kivela J. Mak A. H. N. (2011). Attributes that influence the } \\
\text { evaluation of travel dining experience: when east meets west. }\end{array}$ & 15 & 2011 \\
\hline $\begin{array}{l}\text { Kim Y. G. Eves A. (2012). Construction and validation of a scale to } \\
\text { measure tourist motivation to consume local food }\end{array}$ & 11 & 2012 \\
\hline $\begin{array}{l}\text { Okumuş B. Okumus F. McKercher (2007). Incorporating local and } \\
\text { international cuisines in the marketing of tourism destinastions: the cases } \\
\text { of hong kong and turkey }\end{array}$ & 8 & 2007 \\
\hline $\begin{array}{l}\text { Everett S. (2008). The role of food tourism in sustaining regional identity: } \\
\text { A case study of Cornwall, South West England }\end{array}$ & 8 & 2008 \\
\hline $\begin{array}{l}\text { Gossling S. Garrod B. Aall C. Hille J. Peeters. P. (2011). Food } \\
\text { management in tourism: Reducing tourism's carbon 'foodprint'. }\end{array}$ & 8 & 2011 \\
\hline
\end{tabular}

Tablo 9 atıf kaynaklarının aldıkları atıf sayılarını göstermektedir. Turizm ve yiyecek tüketimi konusunda en fazla atıf alan kaynak Kim Y. G. Eves A. Scarles C. tarafından 2009 yılında yayınlanan makaledir. Bu şekliyle bu makalenin alana ışık tutan önemli bir çalışma olduğu söylenebilir. Bunlara ek olarak Mak A. H. N. Lumbers M. Eves A. tarafından yazılan turizmde küreselleşme ve yiyecek tüketimi; Sims R. tarafından yazılan yerel yiyecek ve sürdürülebilir turizm deneyimi konusundaki makale ile Chang R. C. Y. Kivela J. Mak A. H. N. tarafından yayınlanan Çinli turistlerin yiyecek tercihlerinin ele alındığı çalışma en güncel atıf kaynakları olarak göze çarpmaktadır. 
Tablo 10: Atıf Kaynaklarının Merkezilik Derecesi

\begin{tabular}{|l|l|l|}
\hline Yayınlar & Merkezilik & Y.l \\
\hline $\begin{array}{l}\text { Kim Y. G., Suh B. W. ve Eves A. (2010). The relationship between food- } \\
\text { related personality traits, satisfaction and loyalty among visitors } \\
\text { attending food events and festivals. }\end{array}$ & 0,13 & 2010 \\
\hline $\begin{array}{l}\text { Kim Y. G. Eves A. Scarles C. (2013). Empirical verification of a } \\
\text { conceptual model of local food consumption at a tourist destination. }\end{array}$ & 0,13 & 2013 \\
\hline $\begin{array}{l}\text { Mak A. H. N. Lumbers M. Eves A. Chang R. C. Y. (2012) Factors } \\
\text { influencing tourist food consumption. }\end{array}$ & 0,11 & 2012 \\
\hline $\begin{array}{l}\text { Kim Y. G. Eves A. Scarles C. (2009). Building a model of local food } \\
\text { consumption on trips and holidays: A grounded theory approach. }\end{array}$ & 0,10 & 2009 \\
\hline $\begin{array}{l}\text { Mak A. H. N. Lumbers M. Eves A. (2012). Globalisation and food } \\
\text { consumption in tourism. }\end{array}$ & 0,09 & 2012 \\
\hline $\begin{array}{l}\text { Chang R. C. Y. Kivela J. Mak A. H. N. (2010). Food preferences of } \\
\text { chinese tourists. }\end{array}$ & 0,06 & 2010 \\
\hline $\begin{array}{l}\text { Chang R. C. Y. Kivela J. Mak A. H. N. (2011). Attributes that influence } \\
\text { the evaluation of travel dining experience: when east meets west. }\end{array}$ & 0,04 & 2011 \\
\hline $\begin{array}{l}\text { Horng J. Su C. So S. A. (2013). Segmenting food festival visitors: } \\
\text { applying the theory of planned behavior and lifestyle. }\end{array}$ & 0,04 & 2013 \\
\hline $\begin{array}{l}\text { Bjork P. Kauppinen-Raisanen, H. (2009). Exploring the multi- } \\
\text { dimensionality of travellers' culinary-gastronomic experiences. }\end{array}$ & 0,03 & 2009 \\
\hline $\begin{array}{l}\text { Chang S. J. Witteloostuijn A. Eden L. (2010). From the Editors: } \\
\text { Common method variance in international business research. }\end{array}$ & 0,03 & 2010 \\
\hline
\end{tabular}

Tablo 10 atıf kaynaklarının merkezilik derecesi ile ilgili bilgiler sunmaktadır. Bu çerçevede en yüksek merkezilik derecesine sahip olan kaynakların Kim Y. G. Suh B. W. Eves A. (2010) tarafından yazılan yiyecekle ilgili etkinliklere ve festivallere katılan turistlerin yiyecekle ilgili kişilik özellikleri, memnuniyet ve sadakat ilişkisini inceleyen makale ile Kim Y. G., Eves A. ve Scarles C. (2013) tarafından yazılan turistik destinasyondaki yerel yiyecek tüketimi üzerine gerçekleştirilen kavramsal modelin deneysel doğrulamasını içeren makaleler olduğu anlaşılmaktadır. Bu çalışmaların farklı disiplinler için de önemli birer referans kaynak oldukları söylenebilir.

\section{Şekil 3: Yayın Ortak Atıf Ağı}

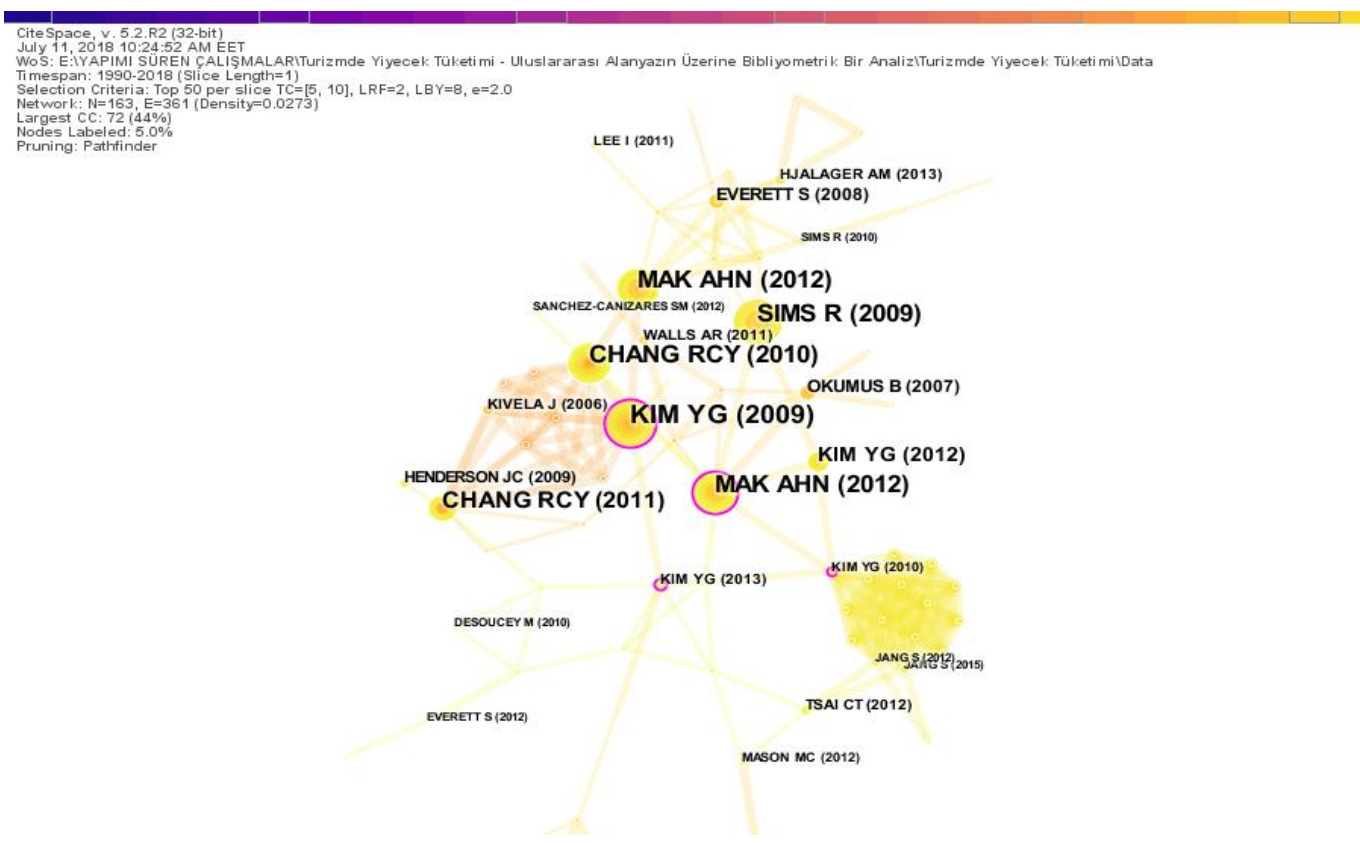


Yayın ortak atıf ağı Şekil 3’te sunulmuştur. Ağ 163 düğüm (atıf kaynağı), bu yayınların meydana getirdiği 361 bağlantı ve 57 kümeden oluşmaktadır. Ağın yoğunluğu 0,0273; mean silhouette değeri 0,3402 modularity değeri de $Q=0,7765$ 'tir. Söz konusu değerler ağın homojene yakın ve yeterli kümeye sahip olduğu göstermektedir.

Tablo 11: Dergi Ortak Atıf Ağı

\begin{tabular}{|c|c|c|c|c|c|}
\hline Dergiler & Frekans & YıI & Dergiler & Merkezilik & YII \\
\hline Tourism Management & 111 & 2011 & $\begin{array}{l}\text { Tourism and Gastronomy } \\
\text { (Kitap) }\end{array}$ & 0,37 & 2012 \\
\hline Annals of Tourism Research & 104 & 2012 & Nature & 0,27 & 2012 \\
\hline $\begin{array}{ll}\text { International Journal of } \\
\text { Hospitality Management }\end{array}$ & 64 & 2012 & Journal of Marketing & 0,24 & 2013 \\
\hline $\begin{array}{l}\text { Journal of Sustainable } \\
\text { Tourism }\end{array}$ & 57 & 2012 & Journal of Travel Research & 0,23 & 2012 \\
\hline Journal of Travel Research & 44 & 2012 & Tourist Studies & 0,22 & 2014 \\
\hline $\begin{array}{l}\text { Tourism and Gastronomy } \\
\text { (Kitap) }\end{array}$ & 38 & 2012 & Food Quality and Preference & 0,21 & 2012 \\
\hline $\begin{array}{l}\text { Journal of } \\
\text { Research }\end{array}$ & 37 & 2013 & Tourism Management & 0,20 & 2011 \\
\hline Appetite & 34 & 2012 & Journal of Business Research & 0,20 & 2013 \\
\hline Sociologia Ruralis & 34 & 2012 & British Food Journal & 0,18 & 2012 \\
\hline British Food Journal & 34 & 2012 & $\begin{array}{l}\text { International Journal } \\
\text { Tourism Research }\end{array}$ & 0,17 & 2013 \\
\hline
\end{tabular}

Tablo 11 dergi ortak ağı hakkında bilgi vermektedir. Turizm ve yiyecek tüketimi konusunun en fazla Tourism Management dergisinde $(n=111)$ ele alındığı görülmektedir. Ağda en merkezi konumda Tourism and Gastronomy yer almaktadır. İlgili kaynak bu konudaki kilit çalışmaların yayımlandığı kaynak olarak ifade edilebilir. Dergilerin çoğunluğunun turuncu renkte gösterilmesi bu çalışmaların çoğunun son yıllarda yayımlandığını, diğer bir ifadeyle güncel olduklarını göstermektedir.

\section{Şekil 4: Ülke İş Birliktelikleri}

CiteSpace, V. 5.2.R2 (32-bit)

June 18, 2018 11:35:14 AM EET
WoS: E:IYAPIMI SUREN CALIŞMALARITurizmde Yiyecek Tüketi mi - Uluslararası Alanyazın Üzerine Bibliyometrik Bir AnalizlTurizmde Yiyecek Tüketi mi lData

Timespan: $1990-2018$ (Slice Length $=1$ )
Selection Criteria: Top 50 per slice $T C=[5,10], \mathrm{LRF}=2, \mathrm{LBY}=8, e=2.0$
Network: $\mathrm{N}=22$, $E=22$ (Density $=0.0952$ ) Largest CC: $19(86 \%)$

\section{ENGLAND}

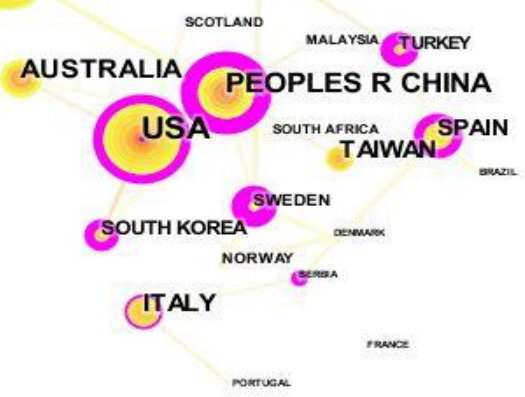


Araştırmanın son bölümünde yer alan Şekil 4'te ülke iş birlikteliklerine ait bulgulara yer verilmiştir. Ağda görülen her bir düğüm bir ülkeyi; bağlantılar ise bu ülkeler arasındaki ilişkileri göstermektedir. Ağdaki renklendirmeler yukarıdaki zaman çizelgesinde görüldüğü şekilde işbirlikteliklerin gerçekleştirildiği yılları temsil etmektedir. Turuncu renk güncel çalışmaları ifade etmektedir. Bağlantı renklerinin çoğunlukla turuncu olması iş birlikteliklerin yakın zamanda olduğu gösterir. Düğümlerin etrafında yer alan pembe çember ise merkezilikle ilgilidir. Pembe çemberin kalınlığı ve boyutu merkezilik derecesinin yüksek olduğunu gösterir (Güzeller ve Çelikler, 2017). Yapılan analizlerde 22 düğüm ve 22 bağlantıdan oluşan bir ağa ulaşılmıştır. Söz konusu ağ 7 kümeden oluşmaktadır ve yoğunluğu 0.0952 'dir. Ağın modularity değeri, $Q=0,6662$; mean silhouette değeri ise 0,4524 olarak bulunmuştur. Bu noktada ağın homojene yakın olduğu ve yeterince kümeye ayrıldığı görülmektedir. Ağda önemli yeri olan ilk 10 ülkenin ağ değerlerine Tablo 12'de ayrıntılı olarak yer verilmiştir.

Tablo 12: Ülke İş Birliktelikleri ve Merkezilik Dereceleri

\begin{tabular}{|l|l|l|l|l|l|}
\hline Ülkeler & Frekans & YIl & Ülkeler & Merkezilik & YIl \\
\hline İngiltere & 36 & 2009 & Çin & 0,93 & 2010 \\
\hline ABD & 32 & 1999 & İsveç & 0,90 & 2015 \\
\hline Çin & 22 & 2010 & Hollanda & 0,69 & 2015 \\
\hline Avustralya & 17 & 2010 & Türkiye & 0,62 & 2011 \\
\hline İtalya & 13 & 2012 & İspanya & 0,56 & 2015 \\
\hline Tayvan & 13 & 2011 & Güney Kore & 0,53 & 2012 \\
\hline İspanya & 12 & 2015 & ABD & 0,27 & 1999 \\
\hline Güney Kore & 7 & 2012 & Sırbistan & 0,30 & 2016 \\
\hline Türkiye & 6 & 2011 & İtalya & 0,16 & 2012 \\
\hline İsveç & 5 & 2015 & İngiltere & 0,00 & 2009 \\
\hline
\end{tabular}

Tablo 12 ülke iş birliktelikleri ile ülkelerin merkezlik dereceleri konusunda bilgiler sunmaktadır. Buna göre İngiltere'nin en fazla işbirliği için de yer aldığı $(n=36)$; Çin'in ise en yüksek merkezilik $(C=0,93)$ derecesine sahip olduğu görülmektedir. Bu noktada Çin'in ülkeler arasındaki bilimsel ilişkilerin sağlanması konusunda bir köprü görevi gördüğü ifade edilebilir.

\section{Tartışma ve Sonuç}

$\mathrm{Bu}$ çalışma turizm ve yiyecek tüketimi konusunu bibliyometrik araştırma deseni kullanarak analiz etmeyi amaçlamıştır. Bu amaç doğrultusunda "turizm" ve "yiyecek tüketimi" kelimeleri 1970-2018 yıl aralıkları seçilerek taranmış; Web of Science Core Collection veri tabanında yer alan konu ile ilgili 265 çalışmaya ulaşılmıştır. Taranan çalışmalar turizm ve yiyecek tüketimi olgusunun geçmişten günümüze gelişimi ve gelecekteki olası eğilimleri konusunda bilgi sahibi olmaya imkân tanımaktadır. Bu bağlamda yürütülen analizler yayın bilgileri, kelime analizleri, atıf bilgileri ve ülke iş birliktelikleri olmak üzere dört temel boyutta gerçekleştirilmiştir. Yayın bilgileri bakımında turizm ve yiyecek tüketimi konusundaki çalışmaların özellikle 2010'lu yıllardan itibaren büyük bir artış sergilediği; makalelerin ağırlıkta olduğu ve bu alandaki en fazla çalışmanın Hospitality, Leisure, Sports and Tourism alanında yapıldığı görülmektedir. Benzer bulgulara Güzeller ve Çeliker'in (2017) çalışmasında da rastlanmaktadır. Gastronomi üzerine yürütülen çalışmaların bibliyometrik açıdan incelendiği araştırmada analiz edilen araştırmaların yarısından fazlasının $(\% 54,6)$ 2010'lu yıllardan sonra yapıldığı anlaşılmaktadır. Bu durum yiyecek içecek konusundaki akademik ilginin oldukça yeni olduğunu göstermektedir. Araştırma Tourism Management dergisinin turizm ve yiyecek tüketimi konusunda en fazla yayın yapan dergi olduğunu göstermektedir. Benzer biçimde Aydın-Arslan vd. (2016) 
tarafından Science Direct veri tabanında turizm talebini inceleyen çalışmada da Tourism Management dergisinin yayın sayısı bakımından ilk sırada olduğu görülmektedir.

Anahtar kelime analizlerinde ortaya çıkan önemli bulgulardan biri deneyim ve yerel yiyecek kelimelerinin oldukça popüler bir araştırma konusu olarak görülmesidir. Benzer bulgulara Güzeller ve Çeliker'in (2018) çalışmasında da rastlanmıştır. Turizm alanyazınını analiz eden çalışmada deneyim sözcüğü en fazla kullanılan 10 anahtar kelimeden biri olarak görülmektedir. Ayaz ve Türkmen (2018) tarafından yapılan çalışma turizm disiplininin son yıllarda özellikle yiyecek içecekle ilgili araştırmalara yoğun bir biçimde eğildiğini ortaya koymuştur. Bu çalışmalarda da yerel yiyecek, yöresel mutfak, yöresel ürün gibi anahtar kelimelerin son yıllarda turizmle birlikte incelenen popüler araştırma konuları olduğu anlaşılmaktadır.

Yayınlar atıf yönünden ele alındığında büyük çoğunluğunun 1-10 atıfa sahip grupta yer aldıkları görülmektedir. Ortak atıf ağı incelendiğinde en fazla atıf alan yazarın Cohen E.; en merkezi yazarların ise McKercher B. ile Anonymous olarak belirtilen ve ismi belirlenemeyen yazarların olduğu anlaşılmaktadır. En fazla ortak atıf alan çalışma Kim vd. (2009) tarafından yayınlanan tatillerde yerel yiyecek tüketimi üzerine bir model sunan araştırmadır. Bu alandaki en merkezi araştırmalar ise Kim Y. G. Suh B. W. Eves A. (2010) ve Kim Y. G., Eves A. ve Scarles C.'In (2013) çalışmalarıdır. Tourism Management dergisi bu alanda en fazla atıfa sahip olan dergi, Tourism and Gastronomy kitabı ise bu alandaki en merkezi kaynak olarak görülmektedir.

Ülke verimlilikleri incelendiğinde İngiltere, $A B D$, Çin ve Avustralya'nın bu alanda en üretken ülkeler oldukları görülmektedir. Güzeller ve Çeliker (2018) tarafından yapılan ve 5 önemli uluslararası turizm dergisini inceleyen araştırma bulguları da en fazla katkı sağlayan dört ülkenin İngiltere, ABD, Çin ve Avustralya olduğunu ortaya koymuştur.

Bu noktada araştırmanın alanyazına sağladığı katkılardan bahsetmek yararlı olacaktır. Araştırma turizm ve yiyecek içecek konusunda çalışma yapmak isteyen araştırmacılar için bu alana öncülük eden yayınları, ülkeleri, güncel araştırma konularını ve gelecekteki eğilimleri sunarak genel bir çerçeve çizmiştir. Bu sayede akademisyenlere turizm ve yiyecek tüketimi konusunun genel gidişatı konusunda yol gösterici bilgiler sunmaktadır. Akademisyenler bu konu ile ilgili güncel araştırma konuları üzerinde çalışmalar gerçekleştirebilir. Araştırmanın uygulamacılara da katkıları bulunmaktadır. Özellikle araştırmalarda güncel olarak kullanılan yerel yemek ve deneyim anahtar kelimelerinden hareketle uygulamacılar da turistlerin yerel yiyecek tüketim davranışlarını göz önünde bulundurarak yemek deneyimi etkinliklerini zenginleştirmek adına çeşitli girişimlerde bulunabilirler.

Bu katkılara ek olarak çalışmanın bir takım sınırlılıkları da bulunmaktadır. Bunlardan ilki araştırmada kullanılan verilerin sadece Web of Science Core Collection veri tabanından elde edilmesidir. Gelecek araştırmalarda Elsevier Scopus, Science Direct gibi veri tabanları da araştırmaya dahil edilebilir. Araştırma amaçları doğrultusunda analizler yayın bilgileri, kelime analizleri, atıf bilgileri ve ülke iş birliktelikleri olmak üzere dört temel boyutta yürütülmüştür. Gelecekteki araştırmalar atıf konusunda daha derinlemesine katkıda bulunup incelenen yayınların atıf patlamalarını ve kurum iş birlikteliklerini inceleyebilir. 


\section{Kaynakça}

Aydın-Arslan, S. Arslan, E. ve Coşkun, İ. O. (2016), 'Science Direct Veri Tabanında Taranan Dergilerin Bibliyometrik Analizi: Turizm Talebi Üzerine Yapılan Çalışmaların İncelenmesi' 17. Ulusal Turizm Kongresi, Ekim 2016 Muğla, ss. 1446-1459,

Aydınoğlu, A. U. ve Taşkın Z. (2017), 'Origins of Life Research: A Bibliometric Approach' Origins of Life and Evolution of Biospheres, Volume 48, Issue 1, ss. 55-71.

Barrios, M. Borrego, A. Vilagines, A. Olle, C. ve Somoza M. (2008), 'A bibliometric Study of Psychological Research on Tourism' Scientometrics, Vol. 77, No. 3, ss. 453-467.

Bayrakçı, S. ve Akdağ, G. (2016), 'Yerel Yemek Tüketim Motivasyonlarının Turistlerin Tekrar Ziyaret Eğilimlerine Etkisi: Gaziantep'i Ziyaret Eden Yerli Turistler Üzerine Bir Araştırma' Anatolia: Turizm Araştırmaları Dergisi, Cilt 27, Sayı 1, Bahar: ss. 96 - 110.

Beer, S. Edwards, J. Fernandes, C. ve Sampaio F. (2002), 'Regional Food Cultures: Integral to the Rural Tourism Product' İçinde Hjalager A. M., Richards G. (Editörler), 207-223, Tourism and Gastronomy, Londra ve New York, 2002.

Bozok, D. Kılıç, S. N. ve Özdemir S. S. (2017), 'Turizm Literatüründe Kırsal Turizmin Bibliyometrik Analizi' Journal of Human Sciences, 14(1), ss. 187-202.

Chen, C. (2006), 'CiteSpace II: Detecting and Visualizing Emerging Trends and Transient Patterns in Scientific Literature' Journal of The Amerıcan Society For Informatıon Science And Technology, 57(3), ss. 359-377.

Cevizkaya, G. İlsay, S. ve Avcıkurt, C. (2014), 'Turizm Alan Yazınında Engelliler ile İlgili Çalışmaların Bibliyometrik Profili' Gazi Üniversitesi Turizm Fakültesi Dergisi, 2, ss.101-108.

Cohen, E. ve Avieli, N. (2004), 'Food in Tourism: Attraction and Impediment' Annals of Tourism Research, Vol. 31, ss. 755-778.

Corigliano, M. A. (2002), 'The Route to Quality: Italian Gastronomy Networks in Operation' İçinde Hjalager A. M., Richards G. (Editörler), 166-185, Tourism and Gastronomy, Londra ve New York.

Çalışkan, O. (2013), 'Destinasyon Rekabetçiliği ve Seyahat Motivasyonu Bakımından Gastronomik Kimlik' Journal of Tourism and Gastronomy Studies, 1/2, ss. 39-51.

Çiçek, D. ve Kozak, N. (2012), 'Anatolia: Turizm Araştırmaları Dergisi'nde Yayımlanan Hakem Denetimli Makalelerin Bibliyometrik Profili' Türk Kütüphaneciliği, 26/4, ss. 734-756

Du Rand, G. E. Heath, ve E. Alberts, N. (2003), 'The Role of Local and Regional Food in Destination Marketing: a South African Situation Analysis' Journal of Travel \&Tourism Marketing, Vol. 14, No. 3, ss. 97-112.

Eren, R. ve Kuvvetli, M. (2017), 'Çevrimiçi Gastronomi İmajı: Türkiye Restoranlarının Tripadvisor Yorumlarının İçerik Analizi' Turizm Akademik Dergisi, Cilt 4, Sayı 2, ss. 121-138.

Erkol-Bayram, G. Bayram, A. T. ve Karaçar, E. (2017), 'Sürdürülebilir Turizm: Bibliyometrik Analiz' 1. Uluslararası Sürdürülebilir Turizm Kongresi 23-25 Kasım 2017, Kastamonu, ss. 179-186,

Everett, S.(2012), 'Production Places and Consumption Spaces? The Place-making Agency of Food Tourism in Irelandand Scotland' Tourism Geographies, Vol. 14, No. 4 , ss. 535-554.

Fields, K. (2002), 'Demand for the Gastronomy Tourism Product: Motivational Factors, İçinde Hjalager A. M., Richards G. (Editörler), 36-50, Tourism and Gastronomy, Londra ve New York. 
Glanzel, W. (2003), Bibliometrics As A Research Field A Course On Theory And Application Of Bibliometric Indicators.

Güçlü-Nergiz, H. (2014), 'Türkiye'de Lisansüstü Turizm Tezlerinin Bibliyometrik Profili (1990-2013)' VII. Lisansüstü Turizm Öğrencileri Araştırma Kongresi: 04-05 Nisan 2014, Kuşadası, Aydın, ss. 212-221,

Güzeller, C. O. ve Çeliker, N. (2017), 'Geçmişten Günümüze Gastronomi Bilimi: Bibliyometrik Bir Analiz' Journal of Tourism and Gastronomy Studies, 5/Special Issue 2, ss. 88-102.

Güzeller, C. O. ve Çeliker, N. (2018), 'Bibliometric Analysis of Tourism Research for the Period 2007-2016' Advances in Hospitality and Tourism Research, 6 (1), ss. $1-22$.

Hall, C. M. (2011), 'Publish and Perish? Bibliometric Analysis, Journal Ranking and the Assessment of Research Quality in Tourism' Tourism Management, 32(1), ss. 16-27.

Harrington, R. J. (2005), 'Defining Gastronomic Identity: The Impact of Environment and Culture on Prevailing Components, Texture and Flavours in Wine and Food' Journal of Culinary Science and Technology, Vol. 4(2/3), ss. 129-152.

Karagöz, D. ve Kozak N. (2014), 'Anatolia Turizm Araştırmaları Dergisi'nin Bibliyometrik Analizi: Araştırma Konuları ve Kurumlar Arası İş Birliğinin Sosyal Ağ Analizi ile İncelenmesi' Türk Kütüphaneciliği, 28/1, ss. 47-61.

Kim, Y. G. Eves, A. ve Scarles, C. (2009), 'Building a Model of Local Food Consumption on Trips and Holidays: A Grounded Theory Approach' International Journal of Hospitality Management, No. 28, ss. 423-431.

Kivela, J. ve Crotts, J. C. (2006), 'Tourism and Gastronomy: Gastronomy's Influence on How Tourist Experience a Destination' Journal of Hospitality and Tourism Research, Vol. 30, No. 3, ss. 354-377.

Köseoğlu, M. A. Rahimi, R. Okumuş, F. ve Liu, J. (2016), 'Bibliometric Studies in Tourism' Annals of Tourism Research, 61, ss. 180-198.

Li, X. Ma, E. ve Qu, H. (2017), 'Knowledge Mapping of Hospitality Research, a Visual Analysis Using Citespace' International Journal of Hospitality Management, No. 60, ss. 77-93.

Mak, A. H. N. Lumbers, M. Eves, A. ve Chang, R. C. Y. (2012), 'Factors Influencing Tourists' Food Consumption' International Journal of Hospitality Management, No. 31, ss. 928-936.

McBurney ,M. K. ve Novak, P. L. (2002), 'What Is Bibliometrics and Why Should You Care?' Reflections on Communication, ss. 108-114.

Nebioğlu, O. (2017), 'Gastronomik Kimlik ve Gastronomik Turizm Ürünlerinin Sınıflandırılması Üzerine Nitel Bir Araştırma: Alanya Örneği' Journal of Tourism and Gastronomy Studies, 5/2, ss. 39-60.

Özel, Ç. H. ve Kozak, N. (2012), 'Turizm Pazarlaması Alanının Bibliyometrik Profili (2000-2010) ve Bir Atıf Analizi Çalışması' Türk Kütüphaneciliği, 26/4, ss.715733.

Palmer, A. L. Sese, A. ve Montano J. J. 2005), 'Tourism and Statistics Bibliometric Study 1998-2002' Annals of Tourism Research, Vol. 32, No. 1, ss. 167-178.

Quan, S. ve Wang, N. (2004), 'Towards a Structural Model of the Tourist Experience and Illustration From Food Experiences in Tourism' Tourism Management, No.25, ss. 297-305.

Richards, G. (2002), 'Gastronomy: As an Essential Ingredient in Tourism Production and Consumption?' İçinde Hjalager A. M., Richards G. (Editörler), 3-20, Tourism and Gastronomy, Londra ve New York.

Ryu, K. ve Jang S. (2006), 'Intention to Experience Local Cuisine in a Travel Destination: The Modified Theory of Reasoned Action' Journal of Hospitality \& Tourism Research, Vol. 30, No. 4, ss. 507-516. 
Sanchez, A. D. Rama, M. ve Garcia, J. A. (2017), 'Bibliometric Analysis of Publications on Wine Tourism in the Databases Scopus and WoS' European Research on Management and Business Economics, 23, ss. 8-15.

Seo, S. Yun, N. ve Kim, O. Y. (2014), 'Destination Food Image and Intention to eat Destination Foods: A View from Korea' Current Issues in Tourism, 20:2, ss. 135156.

Silkes, C. A. (2012), 'Farmers' Markets: A Case for Culinary Tourism' Journal of Culinary Science \& Technology, No. 10, ss. 326-336.

Sünnetçioğlu, A. Yalçınkaya, P. Olcay, M. ve Mercan, Ş. O. (2017), 'Turizm Alanında Yazılmış Olan Gastronomiye İlişkin Tezlerin Bibliyometrik Profili' Journal of Tourism and Gastronomy Studies, 5/Special Issue 2, ss. 345-354.

Şahin, S. ve Acun A. (2015), 'Turist Rehberliği Alanının Bibliyometrik Profili (Ulusal Turizm Kongreleri Bildirileri)' Balıkesir Üniversitesi Sosyal Bilimler Enstitüsü Dergisi, Cilt: 18 - Sayı: 34, ss. 213-234.

Temizkan, S. P. Çiçek, D. ve Özdemir, C. (2015), 'Sağlık Turizmi Konusunda Yayınlanan Makalelerin Bibliyometrik Profili' International Journal of Human Sciences, 12(2), ss. 394-415.

Tayfun A. Küçükergin, F. G. Ayşen, E. Eren A. ve Özekici, Y. K. (2016). 'Turizm Alanında Yazılan Lisansüstü Tezlere Yönelik Bibliyometrik Bir Analiz' Gazi Üniversitesi Turizm Fakültesi Dergisi, 1, ss. 50-69

Ukşul, E. (2016), Türkiye'de Eğitimde Ölçme ve Değerlendirme Alanında Yapılmış Bilimsel Yayınların Sosyal Ağ Analizi ile Değerlendirilmesi: Bir Bibliyometrik Çalışma, Yayımlanmamış Yüksek Lisans Tezi, Akdeniz Üniversitesi, Eğitim Bilimleri Enstitüsü, Antalya.

Web of Science (2018), 'Introduction' https://clarivate.libguides.com/woscc (03.07.2018).

World Tourism Organization (UNWTO) (2017), 'Second Global Report on Gastronomy Tourism' http://cf.cdn.unwto.org/sites/all/files/pdf/gastronomy_report_web.pdf (02.03.2019).

World Tourism Organization (UNWTO) (2018), 'Understanding Tourism: Basic Glossary' http://cf.cdn.unwto.org/sites/all/files/docpdf/glossaryenrev.pdf (03.07.2018).

Yılmaz, G. (2017), 'Ulusal Turizm Kongrelerinde Gastronomi ve Mutfak Sanatları Alanı ile İlgili Yayınlanan Bildiriler Üzerine Bir Araştırma' Turizm \& Araştırma Dergisi, 6(1), ss. 1-21.

Zencir, E. ve Kozak, N. (2012), 'Sosyal Bilimler Enstitü Dergilerinde Yayınlanan Turizm Makalelerinin Bibliyometrik Profili (2000-2010)' VI. Lisansüstü Turizm Öğrencileri Araştırma Kongresi, 12-15 Nisan 2012, Kemer, Antalya, ss. 673-682. 